\title{
Molecular Regulation of Bone Metastasis Pathogenesis
}

\author{
Meng-Yu Wu ${ }^{a, b} \quad$ Chia-Jung Lic Giou-Teng Yianga,b Yeung-Leung Cheng ${ }^{\mathrm{d}}$ \\ Andy Po-Yi Tsaie Yueh-Tseng Hou ${ }^{a, b, f} \quad$ Yu-Chieh Hog Ming-Feng Hou hi,j \\ Pei-Yi Chuk,l,m
}

\begin{abstract}
aDepartment of Emergency Medicine, Taipei Tzu Chi Hospital, Buddhist Tzu Chi Medical Foundation, New Taipei, 'bepartment of Emergency Medicine, School of Medicine, Tzu Chi University, Hualien, 'Research Assistant Center, Show Chwan Memorial Hospital, Changhua, dDivision of Thoracic Surgery, Department of Surgery, Taipei Tzu Chi Hospital, Buddhist Tzu Chi Medical Foundation, New Taipei City, and School of Surgery, Tzu Chi University, Hualien, eDepartment of Medical Research, Buddhist Tzu Chi General Hospital, Hualien, '́Divison of Medical Education, Taipei Tzu Chi Hospital, Buddhist Tzu Chi Medical Foundation, New Taipei, IInstitute of Eye Research, Buddhist Tzu Chi General Hospital, Tzu Chi University, Hualien, ${ }^{h}$ Department of Surgery, College of Medicine, Kaohsiung Medical University, Kaohsiung, 'Department of Surgery, Kaohsiung Municipal Hsiao Kang Hospital, Kaohsiung, 'Division of Breast Surgery, Kaohsiung Medical University Hospital, Kaohsiung, ${ }^{~}$ School of Medicine, College of Medicine, Fu Jen Catholic University, New Taipei, 'Department of Pathology, Show Chwan Memorial Hospital, Changhua, ' $N$ National Institute of Cancer Research, National Health Research Institutes, Tainan, Taiwan
\end{abstract}

\section{Key Words}

Bone metastasis $•$ Tumor microenvironment $•$ Osteoclast $•$ Osteoblast $•$ Myeloid-derived suppressor cells

\begin{abstract}
Distant metastases are the major cause of mortality in cancer patients. Bone metastases may cause bone fractures, local pain, hypercalcemia, bone marrow aplasia, and spinal cord compression. Therefore, the management of bone metastases is important in cancer treatment. Normal bone remodeling is regulated by osteoprotegerin ligand (OPGL), receptor activator of NF- $k B$ ligand (RANKL), parathyroid hormone-related protein (PTHrP), and other cytokines. In the tumor microenvironment, tumor cells induce a vicious cycle that promotes osteoblastic and osteolytic lesions. Studies support the idea that distant metastases may occur due to the immunosuppressive function of myeloid-derived suppressor cells (MDSCs). These cells inhibit $\mathrm{T}$ cells and natural killer (NK) cells and differentiate into tumor-associating macrophages (TAMs), monocytes, and dendritic cells (DCs). In this review, we summarize studies focusing on the role of MDSCs in bone metastasis and provide a strong foundation for developing anticancer immune treatments and anticancer therapies, in general.
\end{abstract}

M.-Y. Wu and C.-J. Li contributed equally to this work.

Ming-Feng Hou and Pei-Yi Chu

\section{KARGER}

Department of Surgery, Division of Breast Surgery, Kaohsiung Municipal Hsiao Kang Hospital, Kaohsiung Department of Pathology, Show Chwan Memorial Hospital, Changhua (Taiwan); E-Mail mifeho@kmu.edu.tw, chu.peiyi@msa.hinet.net 


\section{Cellular Physiology Cell Physiol Biochem 2018;46:1423-1438 \\ and Biochemistry Published $\begin{aligned} & \text { DOI: 10.1159/000489184 } \\ & \text { (c) } 2018 \text { The Author(s). Published by S. Karger AG, Basel } \\ & \text { www.karger.com/cpb }\end{aligned}$ \\ Wu et al.: Molecular Regulation of Bone Metastasis}

\section{Introduction}

Distant metastases are a major cause of mortality in cancer patients, and of several complications, including pulmonary edema, hollow organs obstruction, and tumor embolism. They also significantly impact survival rate and treatment planning. The bone is the third most common site for metastasis, after the lung and liver [1]. Advanced bone metastases commonly cause skeletal-related problems in patients, including pathological fractures, local pain, hypercalcemia, bone marrow aplasia, and spinal cord compression [2]. The prevention and treatment of bone metastasis is an important concern in current oncology. According to many epidemiological studies, bone metastases show an organspecific pattern of spread, especially in breast and prostate cancer [3-5]. This phenomenon led Paget to propose the "seed and soil" hypothesis in 1889 [1, 6]: the "seed" indicates the dissemination of cancer cells from primary sites and the "soil" refers to the metastatic sites. This hypothesis highlights that the specific organ microenvironment plays a critical role in the development of metastases. In this review article, we summarize the current knowledge regarding the molecular regulation of bone metastasis, focusing on their pathogenesis. The importance of the microenvironment in this context is also discussed, with the purpose of helping develop anticancer immune treatments and anticancer therapies.

\section{Physiological bone remodeling}

The bone is a dynamic tissue regulated by a variety of systemic hormones [7] and is composed of two major kind of cells: osteoblasts and osteoclasts. Osteoblasts are specialized bone-forming cells that develop from pluripotent mesenchymal stem cells via the wingless (Wnt)/ $\beta$-catenin pathway, and express parathyroid hormone (PTH) receptors [8]. The Wnt pathway regulates cell fate determination, cell proliferation and migration, and gene expression through a signal cascade activated by the interaction of secreted glycoproteins with their membrane receptors. Osteoblasts contribute to the expression of osteoclastogenic factors and production of bone matrix [9]. Some osteoblasts become osteocytes, trapped in the bone matrix, that function as mechanosensors, activating osteoblasts and osteoclasts for bone remodeling [10]. Osteoclasts derive from mononuclear precursors and are activated by macrophage colony stimulating factor (M-CSF) and receptor activator of NF- $\kappa B$ ligand (RANKL) secreted by stromal cells or osteoblasts [11]. They break down and digest bone tissue, allowing repair and remodeling of the bones. When bone microdamage or mechanical stress occur, osteocyte apoptosis induces bone remodeling through the sequential phases of activation, resorption, formation, and termination (Fig. 1).

Specifically, damage to the bone matrix induces osteocyte apoptosis and release of osteotropic growth factors and cytokines that increase osteoclastogenesis $[12,13]$. The apoptosis of the osteocytes decreases the secretion of transforming growth factor $\beta$ (TGF- $\beta$ ), which inhibits osteoclastogenesis. The mononuclear monocyte-macrophageosteoclast precursor cells are recruited and activated by osteoblast lineage cells via the osteoclastogenesis-related cytokines RANKL and M-CSF. Systemic hormones such as PTH, 1, 25-dihydroxy vitamin D, estrogen, and calcitonin also play an important role in the regulation of bone remodeling [14-16]. PTH regulates serum calcium $\left(\mathrm{Ca}^{2+}\right)$ concentration upon interaction with its G-protein-coupled receptor on osteoblasts. After activation, the osteoblasts release the chemokine monocyte chemoattractant protein-1 (MCP-1), inducing osteoclast differentiation and bone resorption via the $\mathrm{Ca}^{2+}$ intracellular signaling pathway. The expression of osteoprotegerin (OPG) from osteoblasts, a decoy receptor for RANKL that negatively regulates osteoclastogenesis, is reduced in these conditions [17]. At the same time, the production of MCSF and RANKL is increased to promote osteoclast formation. Osteoblasts secrete matrix metalloproteinases (MMPs), such as MMP-13, to degrade the unmineralized osteoid for osteoclast attachment. During the resorption phase, growth hormones, such as TGF- $\beta$, platelet-derived growth factor (PDGF), and insulin-like growth factor I and II (IGF-I 


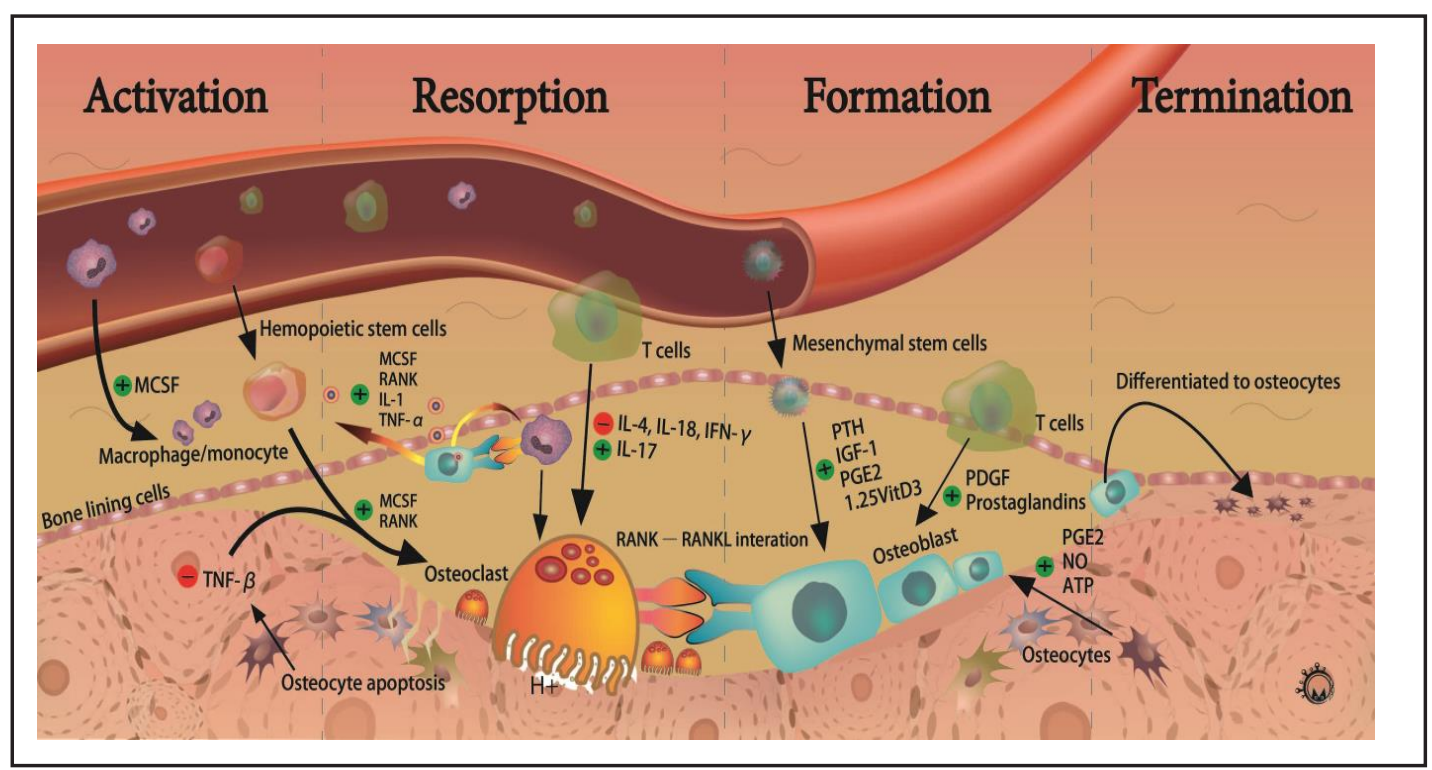

Fig. 1. Mechanism of bone remodeling. Osteoblasts derive from pluripotent mesenchymal stem cells via the wingless (Wnt)/ $\beta$-catenin pathway, and express parathyroid hormone (PTH) receptors; osteoclasts derive from mononuclear precursors, activated by macrophage colony stimulating factor (M-CSF) and receptor activator of NF- $\kappa B$ ligand (RANKL) to digest bone. In bone damage, osteocytes decrease the secretion of transforming growth factor $\beta$ (TGF- $\beta$ ) and promote osteoclastogenesis via M-CSF, RANKL, IL- 1 and TNF- $\alpha$. Systemic hormones, such as PTH, 1,25-dihydroxy vitamin D, estrogen, and calcitonin, promote osteoblasts release the chemokine monocyte chemoattractant protein-1 (MCP-1), inducing osteoclast differentiation and bone resorption via the $\mathrm{Ca}^{2+}$ intracellular signaling pathway. Osteoblasts secrete matrix metalloproteinases (MMPs), such as MMP-13, to degrade the unmineralized osteoid for osteoclast attachment. During the resorption phase, growth hormones, such as TGF- $\beta$, platelet-derived growth factor (PDGF), and insulinlike growth factor I and II (IGF-I and II), regulate the activity of osteoclasts to dissolve the mineral matrix by secreting $\mathrm{H}^{+}$ions. After the resorption of damaged bone, osteoclasts undergo apoptosis and activate osteoblasts to synthesize the osteoid matrix to refill the gap with new bone. Osteocytes also regulate the bone formation by producing prostaglandin $\mathrm{E}_{2}\left(\mathrm{PGE}_{2}\right)$, nitric oxide (NO), and adenosine tri-phosphate (ATP) to stimulate osteoblasts activity. During the termination phase, some osteoblasts differentiate to osteocytes, which become lining cells, secreting inhibitory factors that slow the rate of bone formation.

and II), regulate the activity of osteoclasts. After activation, the osteoclasts attach to the bone surface and dissolve the mineral matrix by secreting $\mathrm{H}^{+}$ions [18]. When the organic matrix is exposed, proteolytic enzymes are released for resorption and digestion, producing the socalled "Howship's resorption lacunae." After the resorption of damaged bone, reversal cells allow the transition from the "resorption" phase to the "formation" phase [19]. Osteoclasts undergo apoptosis and activate osteoblasts. During the bone formation phase, osteoblasts are recruited and differentiate [20]. Under the regulation of local growth factors and hormones, osteoblasts synthesize the osteoid matrix to refill the gap with new bone. In addition, osteocytes can also regulate the bone formation by producing prostaglandin $\mathrm{E}_{2}\left(\mathrm{PGE}_{2}\right)$, nitric oxide (NO), and adenosine tri-phosphate (ATP) to stimulate osteoblasts activity [21]. During the termination phase, some osteoblasts differentiate to osteocytes, which become lining cells, secreting inhibitory factors that slow the rate of bone formation. Finally, a dynamic balance is reached between osteoblast and osteoclast activity, to maintain slow bone resorption and formation. Under normal biological conditions, the bone microenvironment is a dynamic milieu. However, bone metastases may break the balance of the RANK/OPG system, leading to increased bone resorption and local inflammation. 


\section{Cellular Physiology and Biochemistry}

\section{Pathogenesis of bone metastases}

In 1928, James Ewing observed that the liver is a common site of metastasis. He proposed that this happens because the liver is the first organ receiving a large amount of circulating blood and cancer cells from the gastrointestinal tract. This hypothesis was confirmed, and became the so-called "circulation theory" [22]. Current studies indicate that the development of bone metastases is a multistep process [23, 24]. After the tumor has progressed to locally invade the vessels, few disseminated tumor cells are released and evade the immune system, circulating from the primary tumor site to the bone. The tumor cells start colonizing the bone marrow microenvironment and some adapt to the local environment. The tumor cells that survive may grow immediately or enter a dormancy state upon interaction with the local environment. This phase may last several years. Some dormant cells might, at any point, be reactivated, start dividing, and promote the formation of micrometastases (Fig. 2) [25].

The bone is one of the most common sites of cancer metastases. According to published studies, the incidence of bone metastasis in breast, prostate, and thyroid cancer accounts for more than $60 \%$ of the metastases [26] (Table 1). Bone metastases are classified as osteolytic or osteoblastic lesions. Breast cancer metastases are predominantly osteolytic lesions, while metastases originating from prostate cancer are predominantly osteoblastic. However, some patients with bone metastases have mixed osteolytic and osteoblastic lesions. The different mechanisms of bone destruction reflect on the radiological appearance of the metastases. The "seed and soil" mechanism discussed above promotes organotropic attraction of cancer cells to different organs. The pathogenesis of both osteolytic and osteoblastic bone metastasis is discussed below.

\section{Mechanisms of osteoblastic metastases}

In the bone metastatic microenvironment, the tumor cells express adhesion molecules, such as vascular endothelial molecule-1 (VCAM-1), that bind to the integrins $\alpha 4 \beta 7$ and $\alpha 4 \beta 1$ (also called very late antigen-4 [VLA-4]) on osteoclast precursors, inducing the secretion 
of angiogenic and osteoclastogenic factors [27-30]. Cluster of differentiation 44 (CD44), an adhesion molecule expressed by tumor cells, also promotes invasion and adhesion and directly induces bone metastasis [31-33]. In osteoblastic metastases, C-X-C chemokine receptor type 4 (CXCR-4) induces migration and bone metastases by interacting with C-X-C motif ligand 12 (CXCL12) on osteoblasts [34, 35]. After invasion, the tumor cells release several growth factors, inducing a dysfunction in bone remodeling.

In prostate cancer, osteoblastic metastases are common at metastatic sites upon activation of osteoblast activity [36-38]. However, the specific mechanisms of osteoblastic metastases are unknown. Several growth factors released by tumor cells, such as endothelin-1 (ET-1), TGF- $\beta$, IGF-1, fibroblast growth factor (FGF), PDGF, and Wnt, are involved in bone metastasis by promoting tumor cell invasion and increasing the activity of other growth factors and cytokines [39-43]. Studies indicate that ET-1, which is a mitogenic factor for osteoblasts, is found at high concentrations in metastatic sites and that tumor cells release ET-1 to promote osteoblastic metastases through a signaling initiated by the interaction of ET-1 with endothelin A receptor (ETA) [44, 45]. Specifically, ET-1 inhibits the expression of dick kopf 1 (DKK1), a Wnt-signaling antagonist that suppresses bone formation, therefore inducing osteoblasts differentiation [46]. In this regard, it has been found that interference with ET-1 signaling negatively affects the progression of osteoblastic metastases [47].

Urokinase-type plasminogen activator ( $\mathrm{uPA}$ ) is a protease that acts as a mediator to regulate tumor cell proliferation and activation [48], decreases the secretion of osteoclastogenic factors and inhibits bone resorption [49]. Tumor cells also secrete prostate specific antigen (PSA), a kallikrein serine protease that cleaves PTH-related protein (PTHrP) and inhibits the activity of osteoclasts [50]. PSA also activates osteoblasts by stimulating release of several growth factors in the bone metastases, such as IGF-1 and TGF- $\beta$ [51]. The interaction between tumor cells, osteoblasts, and osteoclasts establishes a vicious cycle in osteoblastic metastases (Fig. 3). In clinical practice, PSA is a biomarker indicating disease progression and bone metastases in prostate cancer [52].

Members of the Wnt family are mediators that regulate osteoblasts development and bone formation [53]. Wnt proteins initiate a paracrine activity that promotes the formation of osteoblastic metastases. In prostate cancer, specifically, the expression of DKK-1 decreases during bone metastases progression. The activity of Wnt consequently increases and causes osteoblastic lesions in metastatic site [53-56]. At the same time, and as indicated above, ET-1 also promotes Wnt signaling by inhibiting DKK-1. These data highlight the importance of the tumor microenvironment in bone metastasis.

\section{Mechanisms of osteolytic metastases}

Breast cancer is the most common cancer inducing osteoclastic metastases. The formation of osteolytic lesions is mediated by osteoclasts via the release of several osteoclastogenic factors from tumor cells, such as interleukin-1 (IL-1), IL-6, IL-11, macrophage inflammatory protein 1a (MIP1a), M-CFS, PDGF, RANKL and PTHrP. PTHrP expression is key to promote osteolytic lesions, especially at metastatic bone sites. The expression of PTHrP is higher in bone metastases compared with that in metastases in soft tissues and the primary tumor

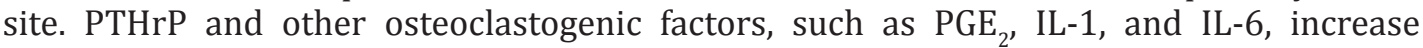
osteoclast activity by inducing the production of RANKL from osteoblasts and stromal cells and decreasing OPG levels [57]. RANK signaling promotes the differentiation of osteoclast 
Fig. 3. Role of osteoblasts and osteoclasts in bone remodeling. In osteoclastic metastases. The formation of osteolytic lesions is mediated by osteoclasts via the release of several osteoclastogenic factors from tumor

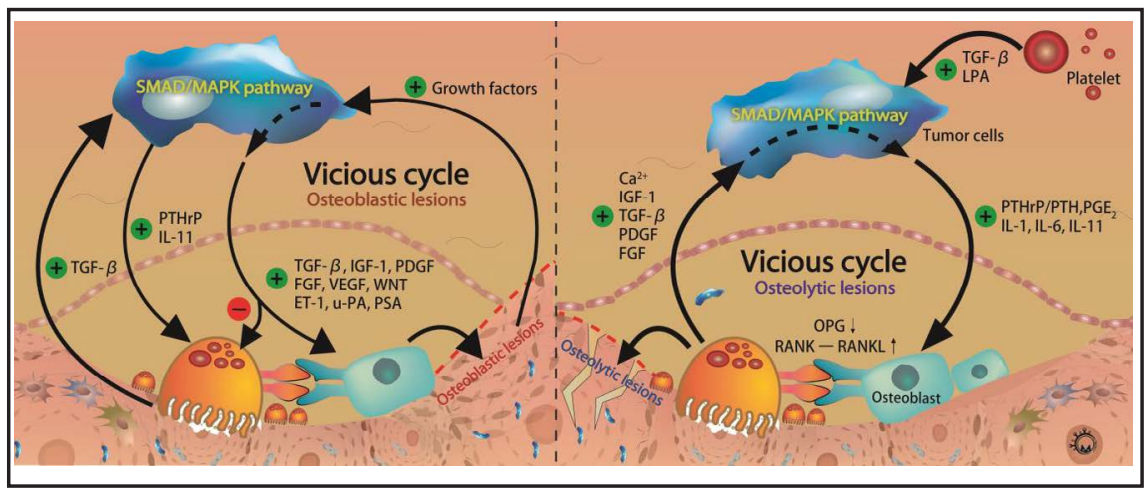
cells, such as inter-

leukin-1 (IL-1), IL-6, IL-11, macrophage inflammatory protein 1a (MIP1a), M-CFS, PDGF, RANKL and PTHrP. PTHrP and other osteoclastogenic factors, such as PGE $_{2}$, IL-1, and IL-6, increase osteoclast activity by inducing the production of RANKL from osteoblasts and stromal cells and decreasing OPG levels. RANK signaling promotes the differentiation of osteoclast progenitors and stimulates bone resorption. After bone resorption, several growth factors stored in the bone matrix, such as TGF- $\beta$, PDGF, IGF-1, and FGF, are released and establish a vicious cycle in osteolytic metastases. In addition, the platelets release TGF- $\beta$ and directly interact with tumor cells. This interaction enhances tumor invasion and metastasis. TGF- $\beta$ and platelet-derived lysophosphatidic acid (LPA), also secreted by platelets, promote osteoclastic activation and bone resorption. In osteoblastic metastases, the tumor cells released several growth factors, such as endothelin-1 (ET-1), TGF- $\beta$, IGF-1, fibroblast growth factor (FGF), PDGF, and Wnt, are involved in bone metastasis by promoting tumor cell invasion and increasing the activity of other growth factors and cytokines Bescides, Urokinasetype plasminogen activator ( $\mathrm{uPA}$ ) and prostate specific antigen (PSA) also increase osteoblast activity and inhibit osteoclasts.

progenitors via transcription factors like nuclear factor kappa B (NF- $\kappa \mathrm{B})$ and activator protein 1 (AP1) and by activating Jun N-terminal kinase (JNK), extracellular signal-regulated kinase 1 and 2 (Erk1/2), and P38 mitogen activated protein kinase (MAPK), thus mediating bone resorption [58-60]. After bone resorption, several growth factors stored in the bone matrix, such as TGF- $\beta$, PDGF, IGF-1, and FGF [61], are released and establish a vicious cycle in osteolytic metastases (Fig. 3).

In the bone microenvironment, the release of TGF- $\beta$ from mineralized bone matrix supports tumor and local cell proliferation through the activation of TGF- $\beta$ type II receptor and the regulatory Smad proteins [62-64]. TGF- $\beta$ also suppresses the proliferation of T-cells and the activity of natural killer cells to inhibit the immune system. Additionally, TGF- $\beta$ promotes the vicious cycle of osteolytic metastases by activating its auto-phosphorylation in tumor cells [65]. After activation, tumor cells show increased proliferation and production of PTHrP. IGF-1 and extracellular $\mathrm{Ca}^{2+}$ are also involved in this vicious cycle [57, 66, 67]. In addition, the platelets release TGF- $\beta$ and directly interact with tumor cells. This interaction enhances tumor invasion and metastasis. TGF- $\beta$ and platelet-derived lysophosphatidic acid (LPA), also secreted by platelets, promote osteoclastic activation and bone resorption (Fig. 3) [68, 69]. The "vicious cycle" described offers a strong foundation for therapeutic intervention. Inhibition of the vicious cycle seems a useful way to arrest tumor progression and bone metastasis. Several studies have focused on targeting TGF- $\beta$, which plays a key role in metastasis in many tumor types, by using TGF- $\beta$ receptor I (TGF $\beta$ RI) inhibitors [70-72]. The results of ongoing clinical trials targeting the TGF- $\beta$ pathway are eagerly awaited [73].

\section{Roles of the immune system in bone metastases}

Bone physiology and the immune system are tightly linked by reciprocal regulation and interaction. Bone cells regulate hematopoietic cells through the expression of surface 


\section{Cellular Physiology Cell Physiol Biochem 2018;46:1423-1438 and Biochemistry Published onlo04ne: April Z3, $2018 \quad \begin{aligned} & \text { DOI 1018 2018 The Author(s). Published by S. Karger AG, Basel } \\ & \text { www.karger.com/cpb }\end{aligned}$

Fig. 4. The role of MDSCs in bone metastases. Initially, hematopoietic stem cells differentiate into common myeloid progenitor cells and immature myeloid cells under the effect of cytokines and growth factors, such as M-CSF, IL-3, and FMS-related tyrosine kinase 3 (FLT-3). In the pathological conditions, a small population of immature myeloid cells are pathologically activated into MDSCs, which is a heterogeneous population of pathologically activated myeloid cells with immunosuppressive function. MDSCs can differentiate into tumor-associated macrophages (TAMs), tumor-associated dendritic cells (TADCs), and tumor-associated neutrophils (TANs), and directly suppress natural killer (NK) cells and $\mathrm{CD}^{+}$ $\mathrm{T}$ cells through the expression of signal mediators as arginase, inducible nitric oxide synthase (iNOS), TGF- $\beta$, IL-10, and cysteine. They release NO and cytokines that suppress $\mathrm{T}$ cells. MDSCs

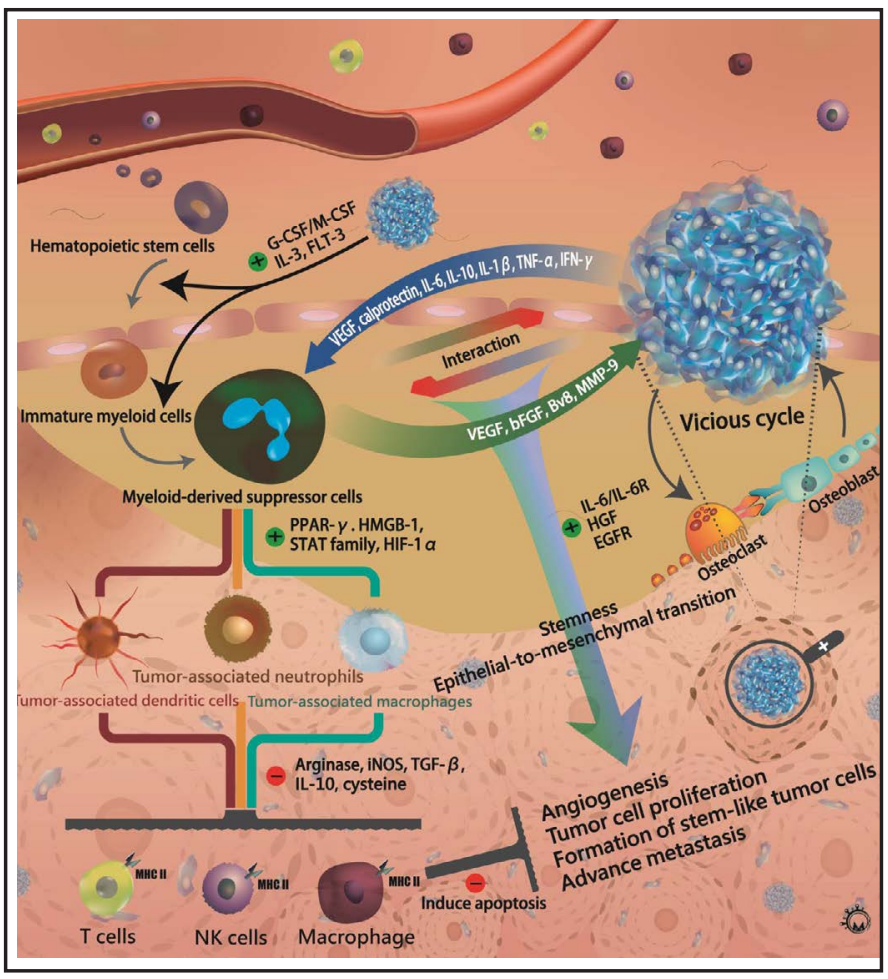
protect the tumor cells from detection of immune system by releasing vascular endothelial growth factor (VEGF), basic FGF (bFGF), the VEGF analogue Bv8, and MMP-9, causing tumor growth and local angiogenesis. Tumor cells secrete several growth factors and cytokines, such as VEGF, calprotectin, IL-6, and IL-10, that recruit and activate MDSCs at the sites of future metastases. MDSCs interact with tumor cells, inducing the release of IL-6 and hepatocyte growth factor (HGF) and epithelial-to-mesenchymal transition (EMT) via the crosstalk between IL-6 receptor (IL6R) and EFG receptor (EGFR), to promote the proliferation of stem cell-like tumor cells, which aggressively induce the progression of metastases.

molecules [74]. The bone and the immune system also share some common pathways [75, 76]. Osteoblasts regulate the proliferation of hematopoietic cells and differentiation of $B$ cells [77]. Osteoclasts derive from mononuclear precursors, which generate macrophages and monocytes as well. RANKL, in particular, is a bridge linking the immune system and bone remodeling [78]. RANKL is indeed expressed not only in osteoblasts but also in T and B cells; additionally, RANKL receptors are expressed by dendritic cells (DCs), monocytes, macrophages, and tumor cells, and the bone and the immune system may interact via the RANKL signaling pathway [78-82]. The immune system can identify tumor-specific antigens or stress ligands produced by transformed cells and expressed on antigen-presenting cells and consequently inhibit the proliferation of tumor cells and metastasis. However, through mechanisms not fully clarified, the transformed cells might escape immune control; this causes bone metastases. Therefore, the immune cells have a critical role in controlling tumor proliferation and invasion within the bone microenvironment.

\section{Role of myeloid-derived suppressor cells (MDSCs) in bone metastases}

MDSCs are a heterogeneous population of pathologically activated myeloid cells with immunosuppressive function; they commonly express the myeloid marker CD33 and lack normal cell-surface markers of monocytes, macrophages, or DCs and the major histocompatibility complex (MHC) class II molecule HLA-DR [83, 84]. Initially, hematopoietic 
stem cells differentiate into common myeloid progenitor cells and immature myeloid cells under the effect of cytokines and growth factors, such as M-CSF, IL-3, and FMS-related tyrosine kinase 3 (FLT-3) [85, 86]. Then, immature myeloid cells differentiate into dendritic cells, monocytes, and macrophages in peripheral organs and tissues. In the pathological conditions existing in the tumor microenvironment, or in the presence of trauma or sepsis, a small population of immature myeloid cells are pathologically activated into MDSCs. MDSCs can differentiate into tumor-associated macrophages (TAMs), tumor-associated dendritic cells (TADCs), and tumor-associated neutrophils (TANs), and directly suppress natural killer (NK) cells and $\mathrm{CD}^{+} \mathrm{T}$ cells through the expression of signal mediators as arginase, inducible nitric oxide synthase (iNOS), TGF- $\beta$, IL-10, and cysteine (Fig. 4) [87-94]. TAMs have stronger immune suppressive ability compared to TANs; they release NO and cytokines that suppress T cells. Specifically, NO nitrates T cell receptors and decreases the function of tumor-associated MHC [95].

\section{Interaction between MDSCs and bone metastases}

The mechanisms through which MDSCs promote the proliferation and metastasis of tumor cells have been reported. Initially, MDSCs protect the tumor cells from detection by the immune system; they regulate the tumor microenvironment in metastatic sites by releasing vascular endothelial growth factor (VEGF), basic FGF (bFGF), the VEGF analogue Bv8, and MMP-9, causing tumor growth and local angiogenesis [96]. Some studies have suggested that a "pre-metastatic niche" originates under the effect of MDSCs, far from the primary tumor, before the appearance of metastases $[97,98]$. According to this hypothesis, primary tumor cells secrete several growth factors and cytokines, such as VEGF, calprotectin, IL-6, and IL10, that recruit and activate MDSCs at the sites of future metastases [99-101]. After the formation of the pre-metastatic niche, MDSCs interact with tumor cells, inducing the release of IL-6 and hepatocyte growth factor (HGF) and epithelial-to-mesenchymal transition (EMT) via the crosstalk between IL-6 receptor (IL-6R) and EFG receptor (EGFR) [102]. Additionally, the interaction between MDSCs and tumor cells promotes the proliferation of stem cell-like tumor cells, which aggressively induce the progression of metastases (Fig. 4) [103, 104]. Therefore, MDSCs play a critical role in the formation of bone metastases.

\section{Mechanisms of activation of MDSCs in bone metastases}

In the tumor microenviroment, MDSCs are mainly activated by M-CSF and granulocyte CSF (G-CSF) secreted from tumor cells and stromal cells. Several proinflammatory cytokines, such as IL-6, IL-1 $\beta$, tumor necrosis factor $\alpha$ (TNF- $\alpha$ ), and interferon $\gamma$ (IFN- $\gamma$ ), stimulate the immunosuppressive abilities of MDSCs. Furthermore, several studies have indicated that members of the signal transducer and activator of transcription (STAT) family and the hypoxia-inducible factor $1 \alpha$ (HIF- $1 \alpha$ ) play important roles in promoting the differentiation of MDSCs [105-111]. Members of the STAT family, including STAT-3, STAT-5 and STAT-6, mediate the activity of MDSCs. STAT-3, in particular, directly binds to the arginase-I promoter to regulate the production of arginase and some studies suggest that the downregulation of the activity of arginase-I, through the inhibition of STAT-3, could reduce the immunosuppressive activity of MDSCs $[112,113]$, indicating the importance of STAT-3 in bone metastasis because of its effect on MDSCs. Metastatic sites are hypoxic; in these conditions, HIF-1 $\alpha$ is expressed and induces the proliferation and immunosuppressive function of MDSCs [114]. Specifically, after the expression and activation of HIF-1 $\alpha$, MDSCs increase their expression of iNOS and arginase-I, leading to the suppression of T cells. Additionally, HIF- $1 \alpha$ regulates expression of immune checkpoint molecules, such as programmed death 1 (PD-1), cytotoxic T-lymphocyte-associated protein 4 (CTLA-4), programmed death ligand 1 and 2 (PD-L1 and PD-L2), CD80 and CD86, on MDSCs, to promote their differentiation into TAMs and 
their immunosuppressive function $[115,116]$. Other mediators, such as high mobility group box 1 (HMGB-1) and peroxisome proliferator-activated receptor gamma (PPAR- $\gamma$ ), have also been reported to regulate MDSCs. HMGB-1 activates MDSCs and promotes their immunosuppressive function, and the induction of PPAR- $\gamma$ expression increases the suppressive activity of TANs on T cells [103, 104, 117].. However, the detailed mechanisms of these processes are unclear. The full understanding of the role of MDSCs might help clarify the mechanisms of immune suppression in the tumor microenviroment and promote new therapeutic interventions.

\section{Therapeutic and molecular interventions}

The concept of the vicious cycle affects the new treatment of bone metastasis. Current stuies support that osteolysis inhibitors might be another treatment to decrease tumour burden [118-120]. Bisphosphonates is a famous bone-targeted agents inhibiting osteoclast activity and decreasing tumour burden [121]. In metastatic site, bisphosphonates tightly bind to the bone matrix and leading osteoclasts apoptosis via higher concentrations. The common side effect include fever, arthralgias, myalgias, bone pain and general malaise. Due to the good effect of controlling activity of osteoclasts, the new-generation bisphosphonates was created, such as pamidronate, zoledronic acid, and ibandronate. New-generation bisphosphonates have different sturcture and known as newer nitrogen-containing bisphosphonates with different mechanism to reguate osteoclastic lesion. Several therapy, such as osteroprotegerin, RANK-Fc, PTHrp antibodies, and Vitamin-D analogues, are under phase I to III studies. Other target therapy, such as anti-MMP-9,anti-IGF-1R, Quercetin, Osthole and activating aromatic hydrocarbon receptor, were reported in rescent $[120,122$ 126]. Current treatments mainly target the RANK-RANKL pathway and PTHrP signaling. However, control the osteroclastgenic factors seems only to reduce tumor burden.

In recent studies, the role of MDSCs in immune escape is a critical role for preventing and decreasing bone metastasis [127, 128]. The strategies of MDSC inhibition was proposed: deactivation, blocking development, and depletion of MDSCs. Several agents were investigated via inhibition of NO, arginase, ROS, and MDSC migration. In vitro studies, the Phosphodiesterase-5 inhibitors degraded the cyclic guanosine monophosphate leading to reduce myeloid-derived suppressor cell function by decreasing the expression of arginase 1 and nitric oxide synthase-2 expression, which mediated the MDSC to induce T cell suppression [129]. The NO production by MDSC may decrease T cell responsiveness via CCL2 and STAT1. The NO-aspirins was promoted to suppress the production of ROS to inhibit nitric oxide synthase-2 expression causing reversal of function of inhibition of T-cell [130-133]. In distant metastasis patients, the colony stimulating factor receptor 1 is an important role to recruit MDSCs to induce angiogenesis. In animal data, the high level of GM-CSF from MDSCs was found in in the spleen and tumor [134, 135]. The inhibitor of colony stimulating factor receptor 1 reduced the recruitment of MDSCs into tumors and inhibited pro-angiogenic and immunosuppressive genes. The monoclonal antibodies targeting colony stimulating factor receptor 1 are undergoing phase I clinical trials. Other potential agents to inhibit MDSC activation and differentiation, including all-trans retinoic acid, Vitamin D3, Vitamin A and $\mathrm{N}$-Bisphosphonates, had a potential effect to control the function of inhibition of T-cell. Although several reported pharmacologic therapies had potential effect in basic studies, the safety and efficacy are necessary to be confirmed by clinical randomized controlled trials in the future.

\section{Conclusion}

In this review, we reported the data from studies focusing on the role of MDSCs in the pathogenesis of bone metastases. We highlighted several principles, worth reiterating here. Normal bone remodeling is regulated by OPGL, RANKL, PTHrP, and other cytokines. Bone 


\section{Cellular Physiology Cell Physiol Biochem 2018;46:1423-1438 \begin{tabular}{lll} 
DOI: 10.1159/000489184 & and Biochemistry & $\begin{array}{l}\text { O } 2018 \text { The Author(s). Published by S. Karger AG, Basel } \\
\text { wwww.karger.com/cpb }\end{array}$ \\
\cline { 2 - 3 }
\end{tabular} \\ Wu et al.: Molecular Regulation of Bone Metastasis}

metastases (both osteoblastic and osteolytic lesions) follow the phases of colonization, dormancy, reactivation, and growth. The secretion of several growth factors generates a vicious cycle that amplifies the signals that induce metastasis. In the tumor microenvironment, MDSCs play an important role in immune escape; their immunosuppressive function inhibits $\mathrm{T}$ and NK cells, leading to the formation of distant metastases. Finally, although the mechanisms associated with immune escape remain unclear, we believe that their understanding will allow the identification of novel targets for therapeutic intervention. This review article provides an overview of the recent reports regarding the molecular regulation of bone metastasis and highlights the role of MDSCs in immune escape, and may help build a strong foundation for developing anticancer immune treatments and anticancer therapies, in general.

\section{Acknowledgements}

This study was funded by grants 103-2314-B-442-002-MY3, 105-2314-B-037-037-MY3, 105-2314-B-037-038-MY3 and 106-2314-B-442-001-MY3 from Ministry of Science and Technology, Taiwan; MOHW106-TDU-B-212-144007 from the Health and Welfare Surcharge of Tobacco Products from Ministry of Health and Welfare, Taiwan; RB17004 and RD106081 and RD106082 from Show Chwan Memorial Hospital, Taiwan; and KMUH105-5R27 form Kaohsiung Medical University Hospital.

\section{Disclosure Statement}

The authors declare no conflict of interest.

\section{References}

1 Mundy GR: Metastasis to bone: causes, consequences and therapeutic opportunities. Nat Rev Cancer 2002;2:584-593.

2 So A, Chin J, Fleshner N, Saad F: Management of skeletal-related events in patients with advanced prostate cancer and bone metastases: Incorporating new agents into clinical practice. Can Urol Assoc J 2012;6:465470.

-3 Chen S-C, Kuo P-L: Bone Metastasis from Renal Cell Carcinoma. International Journal of Molecular Sciences 2016;17:987.

4 Wu X, Shaikh A, Yu Y, Li Y, Ni S, Lu A, Zhang G: Potential Diagnostic and Therapeutic Applications of Oligonucleotide Aptamers in Breast Cancer. International Journal of Molecular Sciences 2017;18:1851.

5 Yin L, Hu Q Hartmann R: Recent Progress in Pharmaceutical Therapies for Castration-Resistant Prostate Cancer. International Journal of Molecular Sciences 2013;14:13958.

6 Sleeman JP: The metastatic niche and stromal progression. Cancer Metastasis Rev 2012;31:429-440.

7 Shi G-X, Zheng X-F, Zhu C, Li B, Wang Y-R, Jiang S-D, Jiang L-S: Evidence of the Role of R-Spondin 1 and Its Receptor Lgr4 in the Transmission of Mechanical Stimuli to Biological Signals for Bone Formation. International Journal of Molecular Sciences 2017;18:564.

8 Crockett JC, Rogers MJ, Coxon FP, Hocking LJ, Helfrich MH: Bone remodelling at a glance. J Cell Sci 2011;124:991-998.

-9 Raisz LG: Physiology and Pathophysiology of Bone Remodeling. Clinical Chemistry 1999;45:1353-1358.

10 Nakashima T, Hayashi M, Fukunaga T, Kurata K, Oh-Hora M, Feng JQ, Bonewald LF, Kodama T, Wutz A, Wagner EF, Penninger JM, Takayanagi H: Evidence for osteocyte regulation of bone homeostasis through RANKL expression. Nat Med 2011;17:1231-1234. 


\section{Cellular Physiology Cell Physiol Biochem 2018;46:1423-1438 \begin{tabular}{l|l} 
and Biochemistry Published onIIne: April 23, 2018 & $\begin{array}{l}\text { (c) } 2018 \text { The Author(s). Published by S. Karger AG, Basel } \\
\text { www.karger.com/cpb }\end{array}$
\end{tabular} \\ Wu et al.: Molecular Regulation of Bone Metastasis}

11 Suda T, Takahashi N, Udagawa N, Jimi E, Gillespie MT, Martin TJ: Modulation of osteoclast differentiation and function by the new members of the tumor necrosis factor receptor and ligand families. Endocr Rev 1999;20:345-357.

12 Parfitt AM: The cellular basis of bone remodeling: the quantum concept reexamined in light of recent advances in the cell biology of bone. Calcif Tissue Int 1984;36 Suppl 1:S37-45.

13 Chambers TJ: The cellular basis of bone resorption. Clin Orthop Relat Res 1980:283-293.

14 Teti A: Bone development: overview of bone cells and signaling. Curr Osteoporos Rep 2011;9:264-273.

-15 Raggatt LJ, Partridge NC: Cellular and molecular mechanisms of bone remodeling. J Biol Chem 2010;285:25103-25108.

16 Tang Y, Wu X, Lei W, Pang L, Wan C, Shi Z, Zhao L, Nagy TR, Peng X, Hu J, Feng X, Van Hul W, Wan M, Cao X: TGF-beta1-induced migration of bone mesenchymal stem cells couples bone resorption with formation. Nat Med 2009;15:757-765.

17 Lacey DL, Timms E, Tan HL, Kelley MJ, Dunstan CR, Burgess T, Elliott R, Colombero A, Elliott G, Scully S, Hsu H, Sullivan J, Hawkins N, Davy E, Capparelli C, Eli A, Qian YX, Kaufman S, Sarosi I, Shalhoub V, Senaldi G, Guo J, Delaney J, Boyle WJ: Osteoprotegerin ligand is a cytokine that regulates osteoclast differentiation and activation. Cell 1998;93:165-176.

18 Bruzzaniti A, Baron R: Molecular regulation of osteoclast activity. Rev Endocr Metab Disord 2006;7:123139.

19 Martin TJ, Sims NA: Osteoclast-derived activity in the coupling of bone formation to resorption. Trends Mol Med 2005;11:76-81.

20 Lian JB, Stein GS: Development of the osteoblast phenotype: molecular mechanisms mediating osteoblast growth and differentiation. Iowa Orthop J 1995;15:118-140.

-21 Xiao W, Wang Y, Pacios S, Li S, Graves DT: Cellular and Molecular Aspects of Bone Remodeling. Front Oral Biol 2016;18:9-16.

22 Sumathi VP, Jeys L, Legdeur N: Metastatic tumours of bone. Surgery (Oxford) 2012;30:80-85.

23 Croucher PI, McDonald MM, Martin TJ: Bone metastasis: the importance of the neighbourhood. Nat Rev Cancer 2016;16:373-386.

24 Fidler IJ: The pathogenesis of cancer metastasis: the 'seed and soil' hypothesis revisited. Nat Rev Cancer 2003;3:453-458.

25 Kan C, Vargas G, Le Pape F, Clézardin P: Cancer Cell Colonisation in the Bone Microenvironment. Int J Mol Sci 2016;17

26 Coleman RE: Metastatic bone disease: clinical features, pathophysiology and treatment strategies. Cancer Treat Rev 2001;27:165-176.

27 Suva LJ, Washam C, Nicholas RW, Griffin RJ: Bone metastasis: mechanisms and therapeutic opportunities. Nat Rev Endocrinol 2011;7:208-218.

28 Pecheur I, Peyruchaud O, Serre CM, Guglielmi J, Voland C, Bourre F, Margue C, Cohen-Solal M, Buffet A, Kieffer N, Clezardin P: Integrin alpha(v)beta3 expression confers on tumor cells a greater propensity to metastasize to bone. Faseb j 2002;16:1266-1268.

29 Chiang AC, Massagué J: Molecular Basis of Metastasis. N Engl J Med 2008;359:2814-2823.

-30 Lu X, Mu E, Wei Y, Riethdorf S, Yang Q, Yuan M, Yan J, Hua Y, Tiede BJ, Lu X, Haffty BG, Pantel K, Massague J, Kang Y: VCAM-1 promotes osteolytic expansion of indolent bone micrometastasis of breast cancer by engaging alpha4beta1-positive osteoclast progenitors. Cancer Cell 2011;20:701-714.

-31 Patel SA, Ramkissoon SH, Bryan M, Pliner LF, Dontu G, Patel PS, Amiri S, Pine SR, Rameshwar P: Delineation of breast cancer cell hierarchy identifies the subset responsible for dormancy. Sci Rep 2012;2:906.

32 Reuben JM, Lee BN, Gao H, Cohen EN, Mego M, Giordano A, Wang X, Lodhi A, Krishnamurthy S, Hortobagyi GN, Cristofanilli M, Lucci A, Woodward WA: Primary breast cancer patients with high risk clinicopathologic features have high percentages of bone marrow epithelial cells with ALDH activity and CD44(+)CD24lo cancer stem cell phenotype. Eur J Cancer 2011;47:1527-1536.

-33 D’Amico L, Patane S, Grange C, Bussolati B, Isella C, Fontani L, Godio L, Cilli M, D’Amelio P, Isaia G, Medico E, Ferracini R, Roato I: Primary breast cancer stem-like cells metastasise to bone, switch phenotype and acquire a bone tropism signature. Br J Cancer 2013;108:2525-2536.

-34 Conley-LaComb MK, Saliganan A, Kandagatla P, Chen YQ, Cher ML, Chinni SR: PTEN loss mediated Akt activation promotes prostate tumor growth and metastasis via CXCL12/CXCR4 signaling. Mol Cancer 2013;12:85. 


\section{Cellular Physiology Cell Physiol Biochem 2018;46:1423-1438 \begin{tabular}{lll} 
DOI: 10.1159/000489184 & and Biochemistry & $\begin{array}{l}\text { O } 2018 \text { The Author(s). Published by S. Karger AG, Basel } \\
\text { www.karger.com/cpb }\end{array}$ \\
\cline { 2 - 3 }
\end{tabular} and al.: Molecular Regulation of Bone Metastasis}

-35 Taichman RS, Cooper C, Keller ET, Pienta KJ, Taichman NS, McCauley LK: Use of the stromal cell-derived factor-1/CXCR4 pathway in prostate cancer metastasis to bone. Cancer Res 2002;62:1832-1837.

-36 Charhon SA, Chapuy MC, Delvin EE, Valentin-Opran A, Edouard CM, Meunier PJ: Histomorphometric analysis of sclerotic bone metastases from prostatic carcinoma special reference to osteomalacia. Cancer 1983;51:918-924.

-37 Roudier MP, Morrissey C, True LD, Higano CS, Vessella RL, Ott SM: Histopathological assessment of prostate cancer bone osteoblastic metastases. J Urol 2008;180:1154-1160.

-38 Coleman RE: The role of bone markers in metastatic bone disease. Cancer Treat Rev 2006;32 Suppl 1:1-2.

-39 Matuo Y, Nishi N, Matsui S, Sandberg AA, Isaacs JT, Wada F: Heparin binding affinity of rat prostatic growth factor in normal and cancerous prostates: partial purification and characterization of rat prostatic growth factor in the Dunning tumor. Cancer Res 1987;47:188-192.

-40 Fudge K, Wang CY, Stearns ME: Immunohistochemistry analysis of platelet-derived growth factor A and $\mathrm{B}$ chains and platelet-derived growth factor alpha and beta receptor expression in benign prostatic hyperplasias and Gleason-graded human prostate adenocarcinomas. Mod Pathol 1994;7:549-554.

41 Funa K, Nordgren H, Nilsson S: In situ expression of mRNA for proto-oncogenes in benign prostatic hyperplasia and in prostatic carcinoma. Scand J Urol Nephrol 1991;25:95-100.

42 Ferrer FA, Miller LJ, Andrawis RI, Kurtzman SH, Albertsen PC, Laudone VP, Kreutzer DL: Vascular endothelial growth factor (VEGF) expression in human prostate cancer: in situ and in vitro expression of VEGF by human prostate cancer cells. J Urol 1997;157:2329-2333.

43 Dai J, Kitagawa Y, Zhang J, Yao Z, Mizokami A, Cheng S, Nor J, McCauley LK, Taichman RS, Keller ET: Vascular endothelial growth factor contributes to the prostate cancer-induced osteoblast differentiation mediated by bone morphogenetic protein. Cancer Res 2004;64:994-999.

44 Takuwa Y, Masaki T, Yamashita K: The effects of the endothelin family peptides on cultured osteoblastic cells from rat calvariae. Biochem Biophys Res Commun 1990;170:998-1005.

45 Nelson JB, Hedican SP, George DJ, Reddi AH, Piantadosi S, Eisenberger MA, Simons JW: Identification of endothelin-1 in the pathophysiology of metastatic adenocarcinoma of the prostate. Nat Med 1995;1:944949.

46 Tian E, Zhan F, Walker R, Rasmussen E, Ma Y, Barlogie B, Shaughnessy JDJ: The Role of the WntSignaling Antagonist DKK1 in the Development of Osteolytic Lesions in Multiple Myeloma. New England Journal of Medicine 2003;349:2483-2494.

47 Nelson JB, Nabulsi AA, Vogelzang NJ, Breul J, Zonnenberg BA, Daliani DD, Schulman CC, Carducci MA: Suppression of prostate cancer induced bone remodeling by the endothelin receptor A antagonist atrasentan. J Urol 2003;169:1143-1149.

48 Guise TA, Mohammad KS, Clines G, Stebbins EG, Wong DH, Higgins LS, Vessella R, Corey E, Padalecki S, Suva L, Chirgwin JM: Basic Mechanisms Responsible for Osteolytic and Osteoblastic Bone Metastases. Clinical Cancer Research 2006;12:6213s-6216s.

49 Bonfil RD, Cher ML: The role of proteolytic enzymes in metastatic bone disease. IBMS BoneKEy 2011;8:1636.

50 Cramer SD, Chen Z, Peehl DM: Prostate specific antigen cleaves parathyroid hormone-related protein in the PTH-like domain: inactivation of PTHrP-stimulated cAMP accumulation in mouse osteoblasts. The Journal of urology 1996;156:526-531.

-51 An H, Tao N, Li J, Guan Y, Wang W, Wang Y, Wang F: Detection of Prostate Cancer Metastasis by Whole Body Magnetic Resonance Imaging Combined with Bone Scintigraphy and PSA Levels. Cell Physiol Biochem 2016;40:1052-1062.

52 Maeda H, Koizumi M, Yoshimura K, Yamauchi T, Kawai T, Ogata E: Correlation between bone metabolic markers and bone scan in prostatic cancer. J Urol 1997;157:539-543.

53 Bennett CN, Longo KA, Wright WS, Suva LJ, Lane TF, Hankenson KD, MacDougald OA: Regulation of osteoblastogenesis and bone mass by Wnt10b. Proc Natl Acad Sci U S A 2005;102:3324-3329.

54 Clines GA, Mohammad KS, Bao Y, Stephens OW, Suva LJ, Shaughnessy JD, Jr., Fox JW, Chirgwin JM, Guise TA: Dickkopf homolog 1 mediates endothelin-1-stimulated new bone formation. Mol Endocrinol 2007;21:486498.

55 Hall CL, Bafico A, Dai J, Aaronson SA, Keller ET: Prostate cancer cells promote osteoblastic bone metastases through Wnts. Cancer Res 2005;65:7554-7560. 


\section{Cellular Physiology Cell Physiol Biochem 2018;46:1423-1438

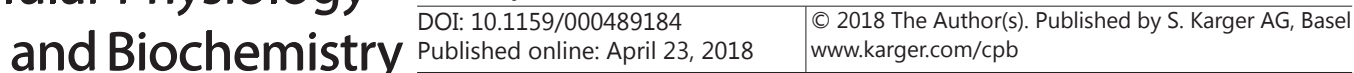 \\ Wu et al.: Molecular Regulation of Bone Metastasis}

56 Hall CL, Keller ET: The role of Wnts in bone metastases. Cancer Metastasis Rev 2006;25:551-558.

57 Yin JJ, Selander K, Chirgwin JM, Dallas M, Grubbs BG, Wieser R, Massagué J, Mundy GR, Guise TA: TGF- $\beta$ signaling blockade inhibits PTHrP secretion by breast cancer cells and bone metastases development. J Clin Invest 1999;103:197-206.

58 Ara T, Declerck YA: Interleukin-6 in bone metastasis and cancer progression. Eur J Cancer 2010;46:12231231.

59 Roodman GD: Mechanisms of bone metastasis. N Engl J Med 2004;350:1655-1664.

-60 Saki N, Abroun S, Farshdousti Hagh M, Asgharei F: Neoplastic bone marrow niche: hematopoietic and mesenchymal stem cells. Cell J 2011;13:131-136.

-61 Mori K, Le Goff B, Charrier C, Battaglia S, Heymann D, Rédini F: DU145 human prostate cancer cells express functional receptor activator of NFKB: New insights in the prostate cancer bone metastasis process. Bone 2007;40:981-990.

62 Shi Y, Massague J: Mechanisms of TGF-beta signaling from cell membrane to the nucleus. Cell 2003;113:685-700.

63 Fournier PG, Chirgwin JM, Guise TA: New insights into the role of T cells in the vicious cycle of bone metastases. Curr Opin Rheumatol 2006;18:396-404.

64 Roberts AB, Sporn MB: Physiological actions and clinical applications of transforming growth factor-beta (TGF-beta). Growth Factors 1993;8:1-9.

65 Kingsley LA, Fournier PGJ, Chirgwin JM, Guise TA: Molecular Biology of Bone Metastasis. Molecular Cancer Therapeutics 2007;6:2609-2617.

66 Bendre MS, Montague DC, Peery T, Akel NS, Gaddy D, Suva LJ: Interleukin-8 stimulation of osteoclastogenesis and bone resorption is a mechanism for the increased osteolysis of metastatic bone disease. Bone 2003;33:28-37.

67 Logothetis CJ, Lin SH: Osteoblasts in prostate cancer metastasis to bone. Nat Rev Cancer 2005;5:21-28.

68 Psaila B, Lyden D, Roberts I: Megakaryocytes, Malignancy and Bone Marrow Vascular Niches. J Thromb Haemost 2012;10:177-188.

69 Boucharaba A, Serre CM, Gres S, Saulnier-Blache JS, Bordet JC, Guglielmi J, Clezardin P, Peyruchaud O: Platelet-derived lysophosphatidic acid supports the progression of osteolytic bone metastases in breast cancer. J Clin Invest 2004;114:1714-1725.

70 Mohammad KS, Chen CG, Balooch G, Stebbins E, McKenna CR, Davis H, Niewolna M, Peng XH, Nguyen DH, Ionova-Martin SS, Bracey JW, Hogue WR, Wong DH, Ritchie RO, Suva LJ, Derynck R, Guise TA, Alliston T: Pharmacologic inhibition of the TGF-beta type I receptor kinase has anabolic and anti-catabolic effects on bone. PLoS One 2009;4:e5275.

71 Conrotto P, Yakymovych I, Yakymovych M, Souchelnytskyi S: Interactome of transforming growth factorbeta type I receptor (TbetaRI): inhibition of TGFbeta signaling by Epac1 J Proteome Res 2007;6:287-297.

72 Melisi D, Ishiyama S, Sclabas GM, Fleming JB, Xia Q Tortora G, Abbruzzese JL, Chiao PJ: LY2109761, a novel transforming growth factor beta receptor type I and type II dual inhibitor, as a therapeutic approach to suppressing pancreatic cancer metastasis. Mol Cancer Ther 2008;7:829-840.

73 Neuzillet C, Tijeras-Raballand A, Cohen R, Cros J, Faivre S, Raymond E, de Gramont A: Targeting the TGFbeta pathway for cancer therapy. Pharmacol Ther 2015;147:22-31.

-74 Aguila HL, Rowe DW: Skeletal development, bone remodeling, and hematopoiesis. Immunol Rev 2005;208:7-18.

75 Takayanagi H: New developments in osteoimmunology. Nat Rev Rheumatol 2012;8:684-689.

76 Kasagi S, Chen W: TGF-beta1 on osteoimmunology and the bone component cells. Cell Biosci 2013;3:4.

77 Arai F, Hirao A, Ohmura M, Sato H, Matsuoka S, Takubo K, Ito K, Koh GY, Suda T: Tie2/angiopoietin-1 signaling regulates hematopoietic stem cell quiescence in the bone marrow niche. Cell 2004;118:149-161.

78 Hofbauer LC, Kuhne CA, Viereck V: The OPG/RANKL/RANK system in metabolic bone diseases. J Musculoskelet Neuronal Interact 2004;4:268-275.

79 Santini D, Perrone G, Roato I, Godio L, Pantano F, Grasso D, Russo A, Vincenzi B, Fratto ME, Sabbatini R, Della Pepa C, Porta C, Del Conte A, Schiavon G, Berruti A, Tomasino RM, Papotti M, Papapietro N, Onetti Muda A, Denaro V, Tonini G: Expression pattern of receptor activator of NFkappaB (RANK) in a series of primary solid tumors and related bone metastases. J Cell Physiol 2011;226:780-784. 


\section{Cellular Physiology Cell Physiol Biochem 2018;46:1423-1438 \begin{tabular}{l|l} 
DOI: 10.1159/000489184 & $\begin{array}{l}\text { O 2018 The Author(s). Published by S. Karger AG, Basel } \\
\text { wwww.karger.com/cpb }\end{array}$
\end{tabular} \\ Wu et al.: Molecular Regulation of Bone Metastasis}

80 Anderson DM, Maraskovsky E, Billingsley WL, Dougall WC, Tometsko ME, Roux ER, Teepe MC, DuBose RF, Cosman D, Galibert L: A homologue of the TNF receptor and its ligand enhance T-cell growth and dendriticcell function. Nature 1997;390:175-179.

81 Kong YY, Yoshida H, Sarosi I, Tan HL, Timms E, Capparelli C, Morony S, Oliveira-dos-Santos AJ, Van G, Itie A, Khoo W, Wakeham A, Dunstan CR, Lacey DL, Mak TW, Boyle WJ, Penninger JM: OPGL is a key regulator of osteoclastogenesis, lymphocyte development and lymph-node organogenesis. Nature 1999;397:315-323.

82 Wong BR, Josien R, Lee SY, Sauter B, Li HL, Steinman RM, Choi Y: TRANCE (tumor necrosis factor [TNF]related activation-induced cytokine), a new TNF family member predominantly expressed in T cells, is a dendritic cell-specific survival factor. J Exp Med 1997;186:2075-2080.

-83 Ochoa AC, Zea AH, Hernandez C, Rodriguez PC: Arginase, prostaglandins, and myeloid-derived suppressor cells in renal cell carcinoma. Clin Cancer Res 2007;13:721s-726s.

84 Almand B, Clark JI, Nikitina E, van Beynen J, English NR, Knight SC, Carbone DP, Gabrilovich DI: Increased production of immature myeloid cells in cancer patients: a mechanism of immunosuppression in cancer. J Immunol 2001;166:678-689.

85 Barbosa CMV, Leon C, Nogueira-Pedro A, Wasinsk F, Araújo RC, Miranda A, Ferreira AT, Paredes-Gamero EJ: Differentiation of hematopoietic stem cell and myeloid populations by ATP is modulated by cytokines. Cell Death Dis 2011;2:e165-.

-86 Seita J, Weissman IL: Hematopoietic Stem Cell: Self-renewal versus Differentiation. Wiley Interdiscip Rev Syst Biol Med 2010;2:640-653.

87 Li H, Han Y, Guo Q, Zhang M, Cao X: Cancer-expanded myeloid-derived suppressor cells induce anergy of NK cells through membrane-bound TGF-beta 1 J Immunol 2009;182:240-249.

88 Huang B, Pan PY, Li Q Sato AI, Levy DE, Bromberg J, Divino CM, Chen SH: Gr-1+CD115+ immature myeloid suppressor cells mediate the development of tumor-induced $\mathrm{T}$ regulatory cells and T-cell anergy in tumorbearing host. Cancer Res 2006;66:1123-1131.

89 Dolcetti L, Peranzoni E, Ugel S, Marigo I, Fernandez Gomez A, Mesa C, Geilich M, Winkels G, Traggiai E, Casati A, Grassi F, Bronte V: Hierarchy of immunosuppressive strength among myeloid-derived suppressor cell subsets is determined by GM-CSF. Eur J Immunol 2010;40:22-35.

90 Movahedi K, Guilliams M, Van den Bossche J, Van den Bergh R, Gysemans C, Beschin A, De Baetselier P, Van Ginderachter JA: Identification of discrete tumor-induced myeloid-derived suppressor cell subpopulations with distinct T cell-suppressive activity. Blood 2008;111:4233-4244.

-91 Elkabets M, Ribeiro VS, Dinarello CA, Ostrand-Rosenberg S, Di Santo JP, Apte RN, Vosshenrich CA: IL-1beta regulates a novel myeloid-derived suppressor cell subset that impairs NK cell development and function. Eur J Immunol 2010;40:3347-3357.

-92 Srivastava MK, Sinha P, Clements VK, Rodriguez P, Ostrand-Rosenberg S: Myeloid-derived suppressor cells inhibit T-cell activation by depleting cystine and cysteine. Cancer Res 2010;70:68-77.

-93 Youn JI, Nagaraj S, Collazo M, Gabrilovich DI: Subsets of myeloid-derived suppressor cells in tumor-bearing mice. J Immunol 2008;181:5791-5802.

-94 Hu CE, Gan J, Zhang RD, Cheng YR, Huang GJ: Up-regulated myeloid-derived suppressor cell contributes to hepatocellular carcinoma development by impairing dendritic cell function. Scand J Gastroenterol 2011;46:156-164.

-95 Lu T, Ramakrishnan R, Altiok S, Youn JI, Cheng P, Celis E, Pisarev V, Sherman S, Sporn MB, Gabrilovich D: Tumor-infiltrating myeloid cells induce tumor cell resistance to cytotoxic T cells in mice. J Clin Invest 2011;121:4015-4029.

-96 Marvel D, Gabrilovich DI: Myeloid-derived suppressor cells in the tumor microenvironment: expect the unexpected. J Clin Invest 2015;125:3356-3364.

-97 Kaplan RN, Psaila B, Lyden D: Bone marrow cells in the 'pre-metastatic niche': within bone and beyond. Cancer Metastasis Rev 2006;25:521-529.

$\$ 98$ Smith HA, Kang Y: The metastasis-promoting roles of tumor-associated immune cells. J Mol Med (Berl) 2013;91:411-429.

-99 Erler JT, Bennewith KL, Cox TR, Lang G, Bird D, Koong A, Le QT, Giaccia AJ: Hypoxia-induced lysyl oxidase is a critical mediator of bone marrow cell recruitment to form the premetastatic niche. Cancer Cell 2009;15:35-44. 


\section{Cellular Physiology Cell Physiol Biochem 2018;46:1423-1438

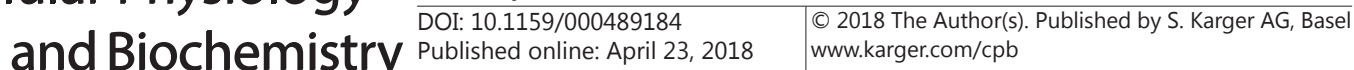

Wu et al.: Molecular Regulation of Bone Metastasis

100 Deng J, Liu Y, Lee H, Herrmann A, Zhang W, Zhang C, Shen S, Priceman SJ, Kujawski M, Pal SK, Raubitschek A, Hoon DS, Forman S, Figlin RA, Liu J, Jove R, Yu H: S1PR1-STAT3 signaling is crucial for myeloid cell colonization at future metastatic sites. Cancer Cell 2012;21:642-654.

101 Hiratsuka S, Watanabe A, Aburatani H, Maru Y: Tumour-mediated upregulation of chemoattractants and recruitment of myeloid cells predetermines lung metastasis. Nat Cell Biol 2006;8:1369-1375.

102 Colomiere M, Ward AC, Riley C, Trenerry MK, Cameron-Smith D, Findlay J, Ackland L, Ahmed N: Cross talk of signals between EGFR and IL-6R through JAK2/STAT3 mediate epithelial-mesenchymal transition in ovarian carcinomas. Br J Cancer 2009;100:134-144.

103 Toh B, Wang X, Keeble J, Sim WJ, Khoo K, Wong W-C, Kato M, Prevost-Blondel A, Thiery J-P, Abastado J-P: Mesenchymal Transition and Dissemination of Cancer Cells Is Driven by Myeloid-Derived Suppressor Cells Infiltrating the Primary Tumor. PLOS Biology 2011;9:e1001162.

104 Cui TX, Kryczek I, Zhao L, Zhao E, Kuick R, Roh MH, Vatan L, Szeliga W, Mao Y, Thomas DG, Kotarski J, Tarkowski R, Wicha M, Cho K, Giordano T, Liu R, Zou W: Myeloid-derived suppressor cells enhance stemness of cancer cells by inducing microRNA101 and suppressing the corepressor CtBP2 Immunity 2013;39:611-621.

105 Gabrilovich DI, Ostrand-Rosenberg S, Bronte V: Coordinated regulation of myeloid cells by tumours. Nat Rev Immunol 2012;12:253-268.

106 Ortiz ML, Kumar V, Martner A, Mony S, Donthireddy L, Condamine T, Seykora J, Knight SC, Malietzis G, Lee GH, Moorghen M, Lenox B, Luetteke N, Celis E, Gabrilovich D: Immature myeloid cells directly contribute to skin tumor development by recruiting IL-17-producing CD4+ T cells. J Exp Med 2015;212:351-367.

107 Condamine T, Gabrilovich DI: Molecular mechanisms regulating myeloid-derived suppressor cell differentiation and function. Trends Immunol 2011;32:19-25.

108 Ortiz ML, Lu L, Ramachandran I, Gabrilovich DI: Myeloid-derived suppressor cells in the development of lung cancer. Cancer Immunol Res 2014;2:50-58.

109 Bayne LJ, Beatty GL, Jhala N, Clark CE, Rhim AD, Stanger BZ, Vonderheide RH: Tumor-derived granulocytemacrophage colony-stimulating factor regulates myeloid inflammation and $\mathrm{T}$ cell immunity in pancreatic cancer. Cancer Cell 2012;21:822-835.

110 Marigo I, Bosio E, Solito S, Mesa C, Fernandez A, Dolcetti L, Ugel S, Sonda N, Bicciato S, Falisi E, Calabrese F, Basso G, Zanovello P, Cozzi E, Mandruzzato S, Bronte V: Tumor-induced tolerance and immune suppression depend on the C/EBPbeta transcription factor. Immunity 2010;32:790-802.

111 Di Mitri D, Toso A, Chen JJ, Sarti M, Pinton S, Jost TR, D’Antuono R, Montani E, Garcia-Escudero R, Guccini I, Da Silva-Alvarez S, Collado M, Eisenberger M, Zhang Z, Catapano C, Grassi F, Alimonti A: Tumour-infiltrating Gr-1+ myeloid cells antagonize senescence in cancer. Nature 2014;515:134-137.

112 Vasquez-Dunddel D, Pan F, Zeng Q, Gorbounov M, Albesiano E, Fu J, Blosser RL, Tam AJ, Bruno T, Zhang H, Pardoll D, Kim Y: STAT3 regulates arginase-I in myeloid-derived suppressor cells from cancer patients. J Clin Invest 2013;123:1580-1589.

113 Abad C, Nobuta H, Li J, Kasai A, Yong WH, Waschek JA: Targeted STAT3 disruption in myeloid cells alters immunosuppressor cell abundance in a murine model of spontaneous medulloblastoma. J Leukoc Biol 2014;95:357-367.

-114 Corzo CA, Condamine T, Lu L, Cotter MJ, Youn JI, Cheng P, Cho HI, Celis E, Quiceno DG, Padhya T, McCaffrey TV, McCaffrey JC, Gabrilovich DI: HIF-1alpha regulates function and differentiation of myeloid-derived suppressor cells in the tumor microenvironment. J Exp Med 2010;207:2439-2453.

115 Ruf M, Moch H, Schraml P: PD-L1 expression is regulated by hypoxia inducible factor in clear cell renal cell carcinoma. Int J Cancer 2016;139:396-403.

116 Noman MZ, Desantis G, Janji B, Hasmim M, Karray S, Dessen P, Bronte V, Chouaib S: PD-L1 is a novel direct target of HIF-1alpha, and its blockade under hypoxia enhanced MDSC-mediated T cell activation. J Exp Med 2014;211:781-790.

117 Ai J, Lu Y, Wei Q, Li H: Comparative Proteomics Uncovers Correlated Signaling Network and Potential Biomarkers for Progression of Prostate Cancer. Cell Physiol Biochem 2017;41:1-9.

118 Diel IJ, Solomayer E-F, Costa SD, Gollan C, Goerner R, Wallwiener D, Kaufmann M, Bastert G: Reduction in New Metastases in Breast Cancer with Adjuvant Clodronate Treatment. New England Journal of Medicine 1998;339:357-363. 


\section{Cellular Physiology Cell Physiol Biochem 2018;46:1423-1438

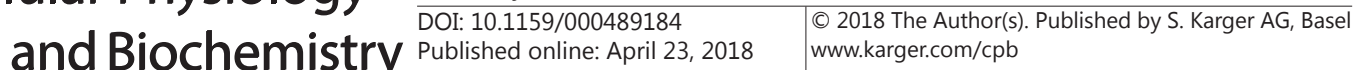

Wu et al.: Molecular Regulation of Bone Metastasis

119 Fisher B, Costantino JP, Wickerham DL, Redmond CK, Kavanah M, Cronin WM, Vogel V, Robidoux A, Dimitrov N, Atkins J, Daly M, Wieand S, Tan-Chiu E, Ford L, Wolmark N: Tamoxifen for prevention of breast cancer: report of the National Surgical Adjuvant Breast and Bowel Project P-1 Study. J Natl Cancer Inst 1998;90:1371-1388.

120 Lan H, Hong W, Fan P, Qian D, Zhu J, Bai B: Quercetin Inhibits Cell Migration and Invasion in Human Osteosarcoma Cells. Cell Physiol Biochem 2017;43:553-567.

121 Casimiro S, Ferreira AR, Mansinho A, Alho I, Costa L: Molecular Mechanisms of Bone Metastasis: Which Targets Came from the Bench to the Bedside? Int J Mol Sci 2016;17

122 Liu Y, Zhang Y, Zou J, Yan L, Yu X, Lu P, Wu X, Li Q Gu R, Zhu D: Andrographolide Induces Autophagic Cell Death and Inhibits Invasion and Metastasis of Human Osteosarcoma Cells in An Autophagy-Dependent Manner. Cell Physiol Biochem 2017;44:1396-1410.

123 Huang S, Guo Y, Jacobi A, Li Z, Huang S, He J, Liu X, Tang Y: Aromatic Hydrocarbon Receptor Suppresses Prostate Cancer Bone Metastasis Cells-Induced Vasculogenesis of Endothelial Progenitor Cells under Hypoxia. Cell Physiol Biochem 2016;39:709-720.

124 Chen G, Fang T, Huang Z, Qi Y, Du S, Di T, Lei Z, Zhang X, Yan W: MicroRNA-133a Inhibits Osteosarcoma Cells Proliferation and Invasion via Targeting IGF-1R. Cell Physiol Biochem 2016;38:598-608.

125 Wang L, Yang L, Lu Y, Chen Y, Liu T, Peng Y, Zhou Y, Cao Y, Bi Z, Liu T, Liu Z, Shan H: Osthole Induces Cell Cycle Arrest and Inhibits Migration and Invasion via PTEN/Akt Pathways in Osteosarcoma. Cell Physiol Biochem 2016;38:2173-2182.

126 Tian X, Zhang X: A Single Nucleotide Polymorphism (rs1056629) in 3'-UTR of MMP-9 is Responsible for a Decreased Risk of Metastatic Osteosarcoma by Compromising its Interaction with microRNA-491-5p. Cell Physiol Biochem 2016;38:1415-1424.

127 Wesolowski R, Markowitz J, Carson WE: Myeloid derived suppressor cells - a new therapeutic target in the treatment of cancer. J Immunother Cancer 2013;1:10.

128 Zhou J, Donatelli SS, Gilvary DL, Tejera MM, Eksioglu EA, Chen X, Coppola D, Wei S, Djeu JY: Therapeutic targeting of myeloid-derived suppressor cells involves a novel mechanism mediated by clusterin. Scientific Reports 2016;6:29521.

129 Serafini P, Meckel K, Kelso M, Noonan K, Califano J, Koch W, Dolcetti L, Bronte V, Borrello I: Phosphodiesterase- 5 inhibition augments endogenous antitumor immunity by reducing myeloid-derived suppressor cell function. J Exp Med 2006;203:2691-2702.

130 Molon B, Ugel S, Del Pozzo F, Soldani C, Zilio S, Avella D, De Palma A, Mauri P, Monegal A, Rescigno M, Savino B, Colombo P, Jonjic N, Pecanic S, Lazzarato L, Fruttero R, Gasco A, Bronte V, Viola A: Chemokine nitration prevents intratumoral infiltration of antigen-specific T cells. The Journal of Experimental Medicine 2011;208:1949-1962.

-131 Fiorucci S, Santucci L, Cirino G, Mencarelli A, Familiari L, Soldato PD, Morelli A: IL-1 beta converting enzyme is a target for nitric oxide-releasing aspirin: new insights in the antiinflammatory mechanism of nitric oxide-releasing nonsteroidal antiinflammatory drugs. J Immunol 2000;165:5245-5254.

132 Nagaraj S, Schrum AG, Cho HI, Celis E, Gabrilovich DI: Mechanism of T cell tolerance induced by myeloidderived suppressor cells. J Immunol 2010;184:3106-3116.

-133 Mundy-Bosse BL, Lesinski GB, Jaime-Ramirez AC, Benninger K, Khan M, Kuppusamy P, Guenterberg K, Kondadasula SV, Chaudhury AR, La Perle KM, Kreiner M, Young G, Guttridge DC, Carson WE, 3rd: Myeloidderived suppressor cell inhibition of the IFN response in tumor-bearing mice. Cancer Res 2011;71:51015110 .

134 De Santo C, Serafini P, Marigo I, Dolcetti L, Bolla M, Del Soldato P, Melani C, Guiducci C, Colombo MP, Iezzi M, Musiani P, Zanovello P, Bronte V: Nitroaspirin corrects immune dysfunction in tumor-bearing hosts and promotes tumor eradication by cancer vaccination. Proc Natl Acad Sci U S A 2005;102:4185-4190.

135 Priceman SJ, Sung JL, Shaposhnik Z, Burton JB, Torres-Collado AX, Moughon DL, Johnson M, Lusis AJ, Cohen DA, Iruela-Arispe ML, Wu L: Targeting distinct tumor-infiltrating myeloid cells by inhibiting CSF-1 receptor: combating tumor evasion of antiangiogenic therapy. Blood 2010;115:1461-1471. 